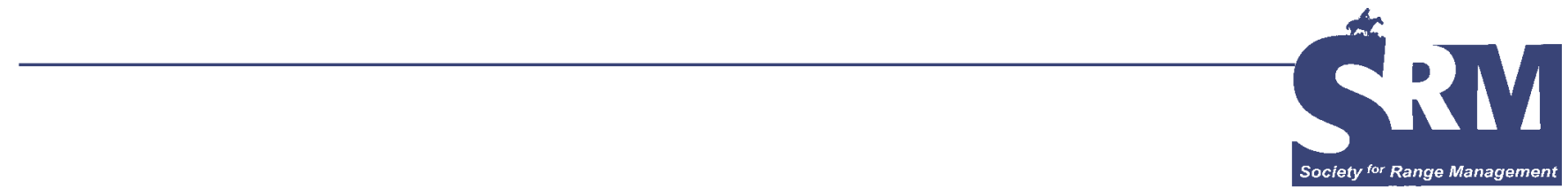

\title{
E. O. Wooton: New Mexico's Pioneer Botanist
}

\section{By Kelly Allred}

When Hiram Hadley first opened the doors of the Las Cruces College in southern New Mexico in 1888, several explorers, scientific collectors, botanists, and naturalists had already criss-crossed the Territory. A youthful William Gambel collected plants in the vicinity of Santa Fe in 1841 and 1842; physician Frederick Adolphus Wislizenus made a rather extensive exploration of the region in 1846; August Fendler botanized the environs of Santa Fe in 1847; and Charles Wright walked across Texas, New Mexico, and Arizona as part of the 1851 survey of the United StatesMexico Boundary, resulting in the discovery of more than 75 New Mexico plants that now bear his name. But when the town of Las Cruces, in the southernmost reaches of New Mexico Territory, won the appointment for the Agricultural College mandated by the Morrill Act of 1862, Hadley's little Las Cruces College was converted to the New Mexico College of Agriculture and Mechanic Arts, and in January 1890, Elmer Ottis Wooton began his appointment as the Territory's first resident plant scientist (Fig. 1).

Born 19 September 1865 in Kokomo, Indiana, Wooton (known to all as E. O.) grew up in a Quaker family in the Indianapolis area. His father, William S. Wooton, was a devoted minister and exceptional furniture maker, who became famous for his patented Cabinet Office Secretary, an elaborate wheeled desk with a myriad of cubby-holes, drawers, nooks, and crannies (John D. Rockefeller, Ulysses S. Grant, Joseph Pulitzer, and Queen Victoria each owned one). The son's first full-time job after graduating from Earlham College in 1889 was his engagement by the fledgling New Mexico College as Professor of Chemistry and Botany, with a corresponding appointment as the Experiment Station Chemist and Botanist, at $\$ 1,000$ per annum.

The little college in the New Mexico desert was in its infancy, and required more from Wooton than just his services as a botanist. He taught, at one time or another, courses in bacteriology, biology, general and economic botany, chemistry, geology, human and plant physiology, mineralogy, physics, and zoology. Nearly every student who matriculated at the college took a class or two from Wooton. According to Paul C. Standley, one of his students who went on to a distinguished botanical career of his own, Wooton was "a born teacher, [and] possessed an extraordinary talent for lucid and practical instruction that held the interest of a student." ${ }^{1}$

Wooton began his botanical activities at the college almost immediately, for the wild West Territory was literally a botanical wilderness, and E. O. set out to discover its wonders. In the University Archives at New Mexico State University are his field notebooks beginning in 1890, and from 11 of his remaining $19 \mathrm{yr}$ in New Mexico. In fact, Wooton often kept two field books. In one he recorded the number, name, and a brief locality for the collections, and in another he entered in more-or-less diary form the itinerary of the trip, including notes on vegetation, grazing effects, geology, erosion, agricultural practices, and personalities met en route (Fig. 2). These journal-style field books contain valuable historical data about the vegetation of the region, as well as providing a fascinating look into the life of a 


\section{Overview of New Mexico}

The state of New Mexico covers a land area of 121,412 square miles $\left(314,433 \mathrm{~km}^{2}\right)$, and ranks as the fifth largest state in the United States. Nearly square, it is 342 miles wide and 370 miles long $(550 \mathrm{~km} \times 595 \mathrm{~km})$, and is about the same size as Poland and about half the size of France. Lying roughly between latitudes of $31^{\circ} \mathrm{N}$ and $37^{\circ} \mathrm{N}$ and longitudes of $103^{\circ} \mathrm{W}$ and $109^{\circ} \mathrm{W}$, the Land of Enchantment sits on the southern border of the United States with Mexico, and is surrounded by the states of Chihuahua (Mexico) and Arizona, Utah, Colorado, Oklahoma, and Texas (United States). From these surrounding states come the Rocky Mountains, the Great Plains, the Chihuahuan Desert, the Mogollon Mountains, and the Colorado Plateau. In fact, all the major land biomes of the world are found within the state, except arctic tundra and tropical rainforest. The highest point in the state is Wheeler Peak in Taos County (13,161 feet; 4,011 m) and the lowest is Red Bluff Reservoir in Eddy County $(2,817$ feet; $859 \mathrm{~m})$. Within the state one finds canyons, valleys, floodplains, badlands, mesas and buttes, bajadas, eroded escarpments, volcanic calderas and necks, lava fields, ash flows, hogbacks, dikes, cuestas, sand dunes, bolsons, playas, alkali flats, Pleistocene lakebeds, karst sinkholes, and glaciated landforms. Temperature extremes have ranged from $-50^{\circ} \mathrm{F}$ to $+116^{\circ} \mathrm{F}\left(-46^{\circ} \mathrm{C}\right.$ to $\left.47^{\circ} \mathrm{C}\right)$ within the state, and a swing of $25-30^{\circ} \mathrm{F}$ in $24 \mathrm{~h}$ at one place is not uncommon. Average annual precipitation varies from less than 8 inches $(200 \mathrm{~mm})$ in the southern deserts to greater than 30 inches $(760 \mathrm{~mm})$ on the northern alpine peaks. All of these factors yield a flora rich and diverse: thrilling to live among, splendid to study, and beautiful to behold!

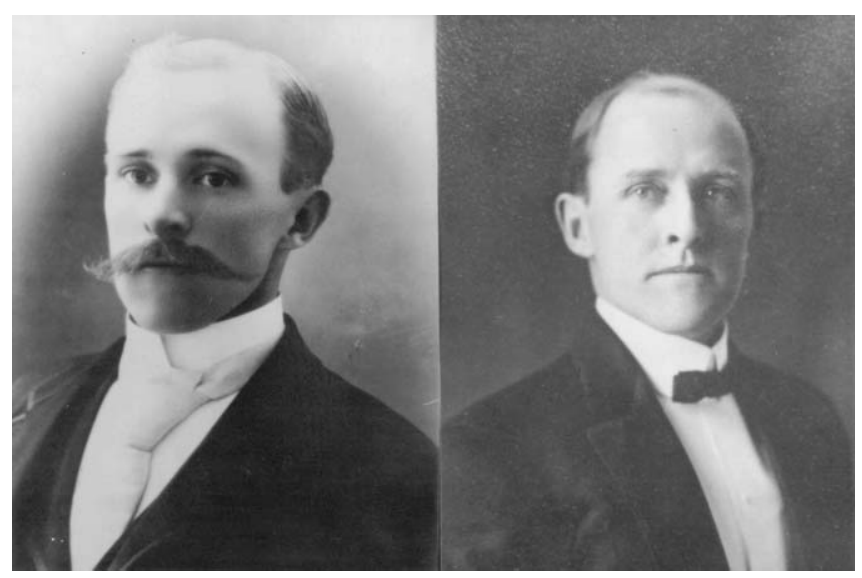

Figure 1. E. O Wooton. Left: 1896, age 31, near the beginning of his New Mexico years. Right: 1908, age 43, near the end of his New Mexico years.

working botanist at the turn of the century. In these journals we find the following from his roamings about the Territory:

In the Southern Rockies (see Appendix), the Chama Valley in north-central New Mexico:

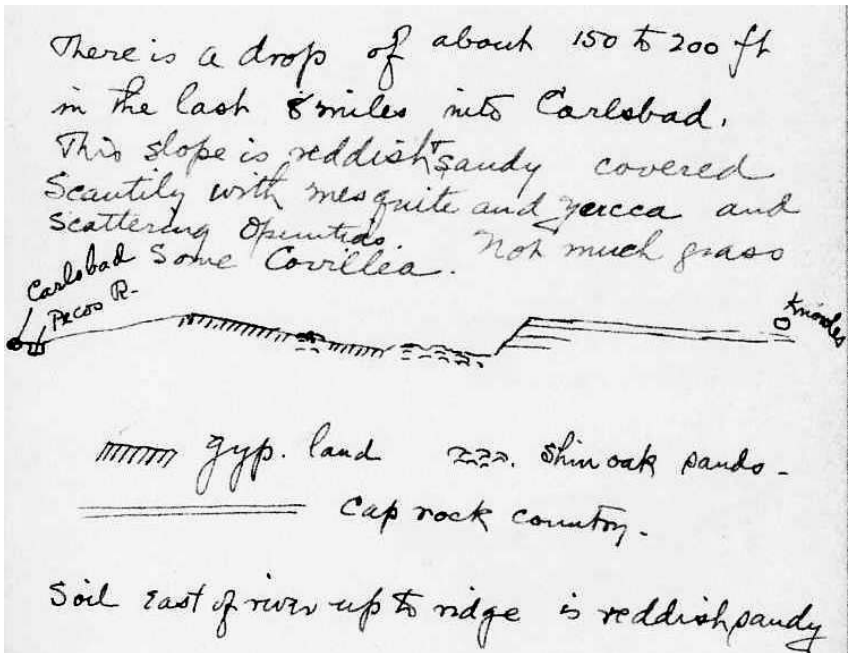

Figure 2. Wooton's field notes from a 1909 trip to the High Plains, showing a transect from Carlsbad east to Knowles.

Lumbering going on throughout the region... Timber has been wasted in large quantities here. ... Aspens E oaks taking the billsides that should be thickly set in conifers. Around Chama E particularly south of the town for the whole distance we came today the pines have been ruthlessly slaughtered. Road winds for miles through the old tops and decaying logs which have been cut EO left to decay or burn... All valuable timber gone. [August 15, 1904]

The coniferous forests had been assaulted to produce up to 400 railroad ties per day for the construction of the narrowgauge rail line connecting Chama and Antonito, Colorado. The immense pine forests were an expendable resource, and they were emaciated by the time Wooton entered the Chama Valley in 1904.

In the Chihuahuan Desert (see Appendix), along the Gila River in southwestern New Mexico:

The river valley grows narrower $\mathcal{E}$ less $E$ less land is available for cultivation. The flood plain of the river is about $1 / 4$ mile wide. Floods are becoming more important all the time. Every feeder of this river sends down a flood whenever there is even a moderate rain over the areas they drain. Then two or three small valleys send in their floods at the same time, the river gets a "boom" and is impassable for hours. And these floods come down small cañons which were formerly all more or less arable lands, but are now barren, rocky, watercourses. There is but one explanation for most of it-overstocking the ranges. The waste is enormous, and increases each year. [August 15, 1902].

Wooton was particularly alert to the cycle of overstocking, depletion of plant cover, increased runoff, erosion and gully formation, and the disappearance of springs and seeps, 


\section{Plant Names Used in the Text}

Alkali sacaton

Arizona oak

Aspen

Black grama

Blue grama

\section{Buffalograss}

Cottonwood

Creosote

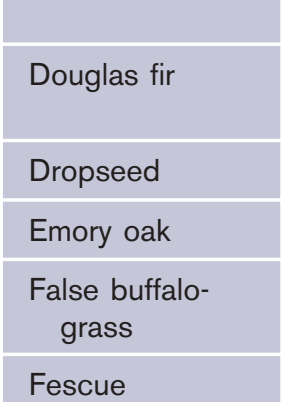

\section{Fir}

Fourwing salt-
bush

Gambel's oak

Grama

\section{Greasewood}

Hairy grama
Indian ricegrass

Juniper

Little bluestem

Mesquite

Mormon tea

Muhly

Oak

One-seed juni-
per

Pine

Piñon
Sporobolus airoides (Torrey) Torrey

Quercus arizonica Sargent

Populus tremuloides Michaux

Bouteloua eriopoda (Torrey) Torrey

Bouteloua gracilis (Willdenow ex Kunth) Lagasca ex Griffiths

Buchloë dactyloides (Nuttall) Engelmann

Populus spp.

Larrea tridentata (Sessé \& Mociño ex A. P. de Candolle) Coville

Pseudotsuga menziesii (Mirbel) Franco

\section{Sporobolus spp.}

Quercus emoryi Torrey

Munroa squarrosa (Nuttall) Torrey

Festuca spp.

Abies spp.

Atriplex canescens (Pursh) Nuttall

Pleuraphis jamesii Torrey

Quercus gambelii Nuttall

Bouteloua spp.

Sarcobatus vermiculatus (Hooker) Torrey

Bouteloua hirsuta Lagasca

Achnatherum hymenoides (Roemer \& J. A. Schultes) Barkworth

Juniperus spp., mostly J. monosperma in New Mexico

Schizachyrium scoparium (Michaux) Nash

mostly Prosopis glandulosa Torrey in New Mexico

Ephedra spp.

Muhlenbergia spp.

Quercus spp.

Juniperus monosperma (Englemann) Sargent

Pinus spp.

Pinus edulis Engelmann

\section{Plant Names Used in the Text (continued)}

\begin{tabular}{|c|c|}
\hline Ponderosa pine & Pinus ponderosa Lawson \\
\hline $\begin{array}{l}\text { Poverty three- } \\
\text { awn }\end{array}$ & $\begin{array}{l}\text { Aristida divaricata Humboldt \& } \\
\text { Bonpland ex Willdenow }\end{array}$ \\
\hline Ring muhly & $\begin{array}{l}\text { Muhlenbergia torreyi (Kunth) } \\
\text { Hitchcock }\end{array}$ \\
\hline Saltbush & Atriplex spp. \\
\hline Sand dropseed & $\begin{array}{l}\text { Sporobolus cryptandrus (Torrey) } \\
\text { Gray }\end{array}$ \\
\hline Sand sagebrush & Artemisia filifolia Torrey \\
\hline Shadscale & $\begin{array}{l}\text { Atriplex confertifolia (Torrey \& } \\
\text { Fremont) S. Watson }\end{array}$ \\
\hline Shin oak & Quercus havardii Rydberg \\
\hline Sideoats grama & $\begin{array}{l}\text { Bouteloua curtipendula (Michaux) } \\
\text { Torrey }\end{array}$ \\
\hline Silver bluestem & $\begin{array}{l}\text { Bothriochloa laguroides (A. P. de } \\
\text { Candolle) Herter subsp. torreyana } \\
\text { (Steudel) Allred \& Gould }\end{array}$ \\
\hline Silverleaf oak & Quercus hypoleucoides A. Camus \\
\hline $\begin{array}{l}\text { Skunkbush } \\
\text { sumac }\end{array}$ & Rhus trilobata Nuttall \\
\hline Spruce & Picea spp. \\
\hline Sycamore & Platanus wrightiii S. Watson \\
\hline Tarbush & Flourensia cernua A. P. de Candolle \\
\hline Threeawn & Aristida spp. \\
\hline $\begin{array}{l}\text { Western wheat- } \\
\text { grass }\end{array}$ & Elymus smithii (Rydberg) Gould \\
\hline Willow & Salix spp. \\
\hline Yucca & Yucca spp. \\
\hline
\end{tabular}

resulting in the almost irreversible degradation of the range. The marginal grazing lands of the Chihuahuan Desert are especially susceptible to this ruinous progression.

On the Southwestern Tablelands (see Appendix), plains about 35 miles south of Santa Fe in central New Mexico:

...found an almost level plain to the south of us.... These plains slope very gently to the southward and the draws are very shallow Eo open. Very little if any erosion. ... Water in holes all along the draws. Wetter bottoms are thickly set in blue grama while galleta, black grama, ring mubly, and sand dropseed occupy the drier gently sloping hillsides. Country flat enough to drive across in nearly any direction. [August 24, 1904].

With adequate moisture, blue grama grasslands are outstanding grazing lands, and resist degradation better than almost 
any other kind of range. Wooton's comments in the summer of 1904 came after several years of severe drought in the Territory, but the plains grasslands were still productive. Notwithstanding their resilience in the face of drought, grama grasslands were not immune to all threats, however, and later years have witnessed the assault of juniper into much of our central plains.

On the High Plains (see Appendix), southeastern New Mexico, near Knowles (Fig. 2):

Cap Rock is a layer of limestone apparently overlying the red sandstone series. Seems to have a slight dip eastward, but is so slight I can't be sure. ... Whole region heavily grassed-with hairy grama (?blue grama?), galleta, buffalograss coming in more and more as you go east [from Carlsbad]. Very ferw bushes of any kind, except low scattering mesquite. ... Cap Rock country said to extend south and north indefinitely, into Texas E Colorado.... The "shin oak" region is a belt about 6 miles wide extending north E south at foot of caprock escarpment. Soil very reddish yellow sand. ... Grass is very scanty. [August 11, 1909].

Here Wooton entered the Llano Estacado region in eastern New Mexico-an elevated, flat plain that was in excellent range condition in his day, even though there were thousands of head of cattle and sheep on the range. The shortgrass plains could withstand the grazing, but it would not survive the plow. Wooton remarked in other notes from this area that more and more terrain was being dry-farmed, in the futile hope that rain would "follow the plow." It did not, and today much of the region that is not in agriculture is now thickly covered with mesquite or shin-oak.

The numerous plant collections gathered by Wooton through the years contributed to the development of the college herbarium. Beginning with nothing in 1890, he had accumulated 13,000 sheets by $1901,18,000$ by $1905,25,000$ by 1908 , and 35,000 by 1911 , Wooton's last year at the college. The records of the herbarium show an ambitious program of plant exchange with most of the botanical notables of his day: Abrams, Baker, Britton, Deam, Garrett, Eastwood, Greene, Griffiths, Heller, Hitchcock, Jones, McKenzie, Nelson, Rose, Rydberg, Shreve, Thornber, Tracy, and Vasey. The University Herbarium in the Biology Department now houses upwards of 75,000 sheets, with nearly all of Wooton's early collections among them.

During his $20 \mathrm{yr}$ of botanizing in New Mexico, Wooton named 231 new species and one new genus of plants, most from his own collections and in partnership with Standley. More than $60 \%$ of his taxa are still recognized. This percentage is rather remarkable, given the extremely liberal taxonomic philosophy to which Wooton subscribed and that prevailed at that time.

In 1911, Wooton took a position with the Office of Farm Management in Washington, DC, with which he held various positions until his retirement in 1935 . He returned periodically to the newly admitted 47th state in the Union, to visit the college and friends and to conduct business for the Department of Agriculture. He even applied for the presidency of the college in 1917, and was awarded an honorary degree of Doctor of Sciences in 1932. Elmer Ottis Wooton died 20 November 1945, and was buried in the city of Arlington, Virginia.

Wooton's botanical work in New Mexico concluded with the publication of Flora of New Mexico in 1915, in collaboration with P.C. Standley. ${ }^{2}$ Its 794 pages recorded the 2903 plant species then known from the state. Although Wooton later called his monograph only a "preliminary list" and a "framework upon which more data might be hung," this prestigious work was the culmination of $20 \mathrm{yr}$ of botanical effort and stood until 1980 as the only scientific manual of New Mexico plants. But Wooton was prescient. Today, his botanical framework is sturdy enough to house nearly a thousand more species recorded for the state. Despite E. O. Wooton's prodigious efforts to botanize New Mexico, an average of 30 or so new species are yet found in the state each year-the Land of Enchantment is still a botanical wilderness.

\section{Acknowledgments}

Many thanks to two anonymous reviewers for their helpful suggestions on the text.

\section{References}

1. Standley, P. C. 1947. E. O. Wooton [Obituaries]. Journal of the Washington Academy of Science 37:34-35.

2. Wooton, E. O., and P. C. Standley. 1915. Flora of New Mexico. Contributions of the U.S. National Herbarium 19:1-794.

3. Griffith, G. E., J. M. Omernik, M. M. McGraw, G. Z. Jacobi, C. M. Canavan, T. S. Schrader, D. Mercer, R. Hill, and B. C. Moran. 2006. Ecoregions of New Mexico (color poster with map, descriptive text, summary tables, and photographs). Reston, VA, USA: US Geological Survey (map scale 1:1,400,000). Available at: http://www.epa.gov/wed/pages/ ecoregions/nm_eco.htm. Accessed 20 August 2008.

\section{Appendix: Ecoregions of New Mexico}

New Mexico can be divided into seven ecoregions, which describe the interacting patterns of the biota, geology, physiography, soils, land use, hydrology, and climate of the state (adapted from Griffith et al. 2006; ${ }^{3}$ for detailed New Mexico NRCS Major Land Resource Areas and Ecological Site Descriptions see www.nm.nrcs.usda.gov/technical/fotg/ section-2/esd.html).

\section{Colorado Plateau}

The Colorado Plateau spills into New Mexico in the northwestern corner of the state, merging into the very similar Arizona/New Mexico Plateau, and containing many of the 


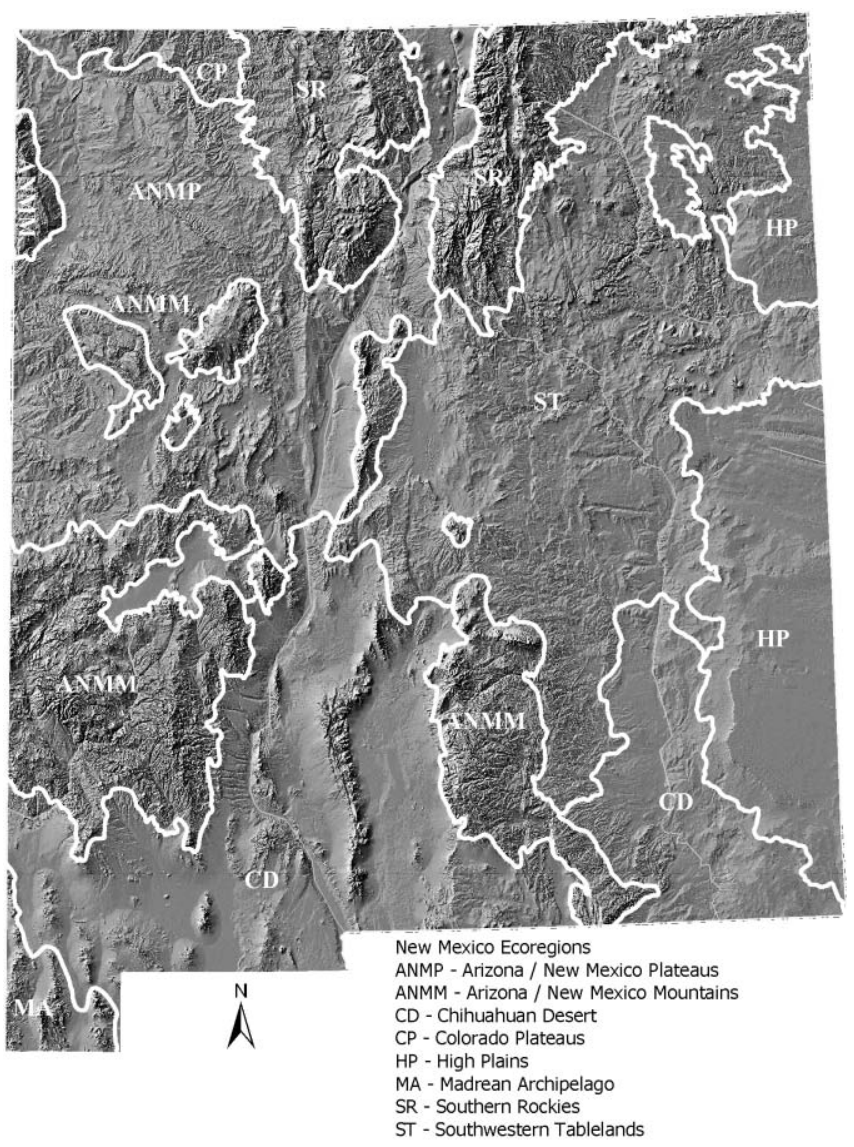

Map of ecoregions in New Mexico.

same plant species. The region contains abundant woodlands of piñon-juniper and Gambel's oak, but also has large low-lying areas sparsely vegetated with various saltbush species and greasewood, and a variety of native grasses, such as alkali sacaton, galleta, poverty threeawn, sand dropseed, and Indian ricegrass.

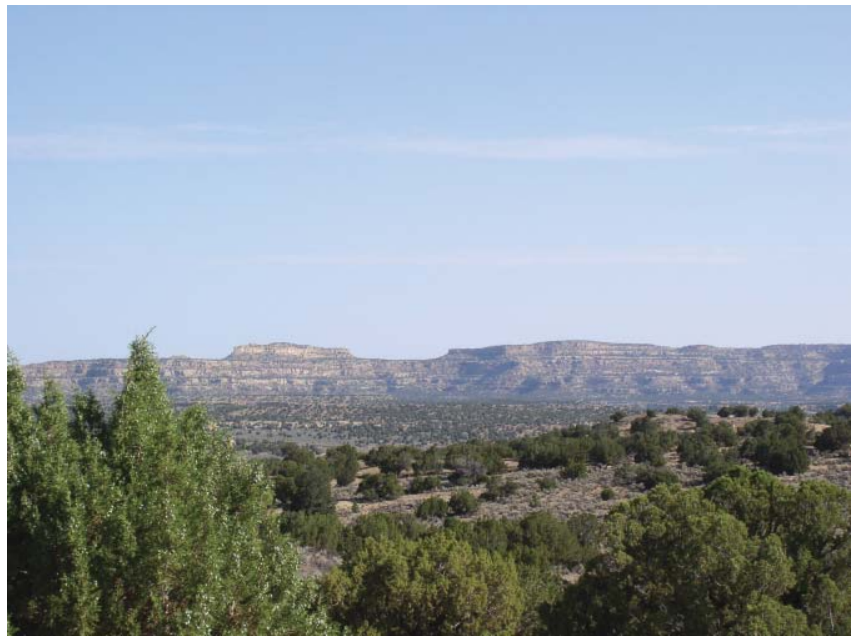

Colorado Plateau near San Juan City, New Mexico. Photo by Santiago Misquez.

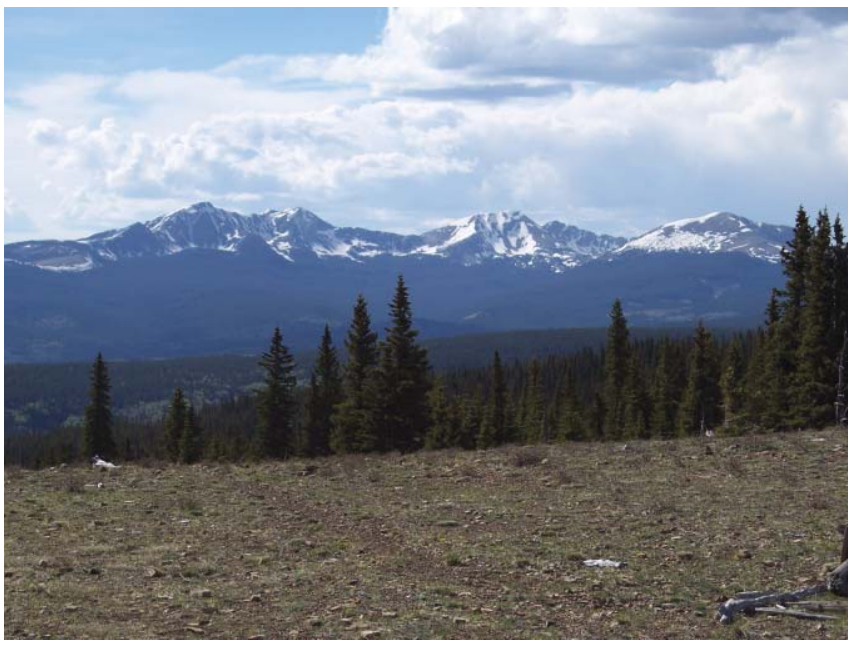

Southern Rockies in Santa Fe National Forest. Photo by Matt Attencio.

\section{Southern Rockies}

The Southern Rockies are composed of high elevation, steep, rugged mountains, and are found in the north-central part of the state. Although coniferous forests cover much of the region, vegetation follows a pattern of elevational banding, and are composed of high elevation alpine meadows and krummholz growth, coniferous forests of spruce, fir, and ponderosa pine, mountain grasslands and parks of various fescue and muhly grasses, and lower elevation woodlands and savannahs dominated by piñon and juniper.

\section{Arizona/New Mexico Plateau}

This is a large transitional region between the drier shrublands and wooded higher relief tablelands of the Colorado Plateau in the north and the forested mountains that border the region on the northeast and south. The Continental Divide splits the region, but is not a prominent topographic feature. The plateau contains a mix of desert scrub, grassland, and piñon-juniper communities dispersed among a varied topography of mesas, valleys, plateaus, and canyons. Much of the area is characterized by shadscale, fourwing

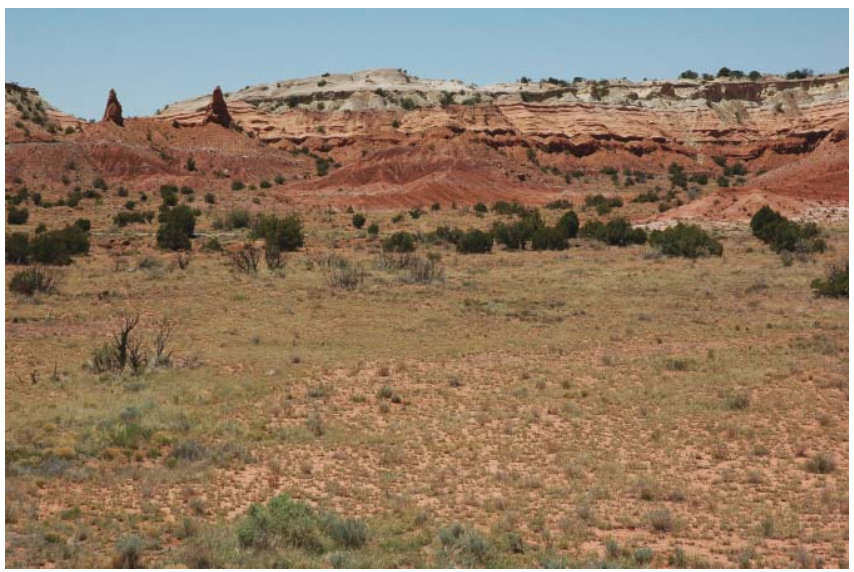

Arizona/New Mexico Plateau: sandstone buttes south of Cuba, New Mexico. Photo by Katie Northrup. 
saltbush, mormon tea, Indian ricegrass, galleta, and blue grama.

\section{Arizona/New Mexico Mountains}

The Arizona/New Mexico Mountains are distinguished from the neighboring Southern Rockies by their lower elevations and vegetation indicative of its drier, warmer environments, due in part to the region's more southerly location. Forests of spruce, fir, and Douglas fir, common in the Southern Rockies ecoregion to the north, are only found in limited areas at the highest elevations in this region. Chaparral is common at lower elevations in some areas, piñon-juniper and oak woodlands are found at lower and middle elevations, and the higher elevations are mostly covered with open to dense ponderosa pine forests. These mountains are the northern extent of some Mexican plant and animal species. Surrounded by deserts or grasslands, these New Mexico mountains can be considered biogeographic islands.

\section{Chihuahuan Desert}

The Chihuahuan Desert extends across the southern, arid lands of New Mexico, with two fingers reaching northward along the Rio Grande and Pecos River basins. It is the northernmost portion of the largest desert in North America, and extends more than 500 miles south into Mexico. The physiography is a continuation of the basin and range topography, although the pattern of alternating mountains and valleys is not as pronounced as it is elsewhere. Outside the major river valleys (Rio Grande, Gila River, and Pecos River) the landscape is largely internally drained, and bolsons and playas are common. Vegetative cover is predominantly desert grassland of gramas, threeawns, and dropseeds, and arid shrubland composed of creosote, mesquite, and tarbush, except for higher elevation islands of oak, juniper, and piñon pine woodland. The interface between the grassland and shrubland is dynamic, both historically and currently, as influenced primarily by drought, grazing, and human disturbance.

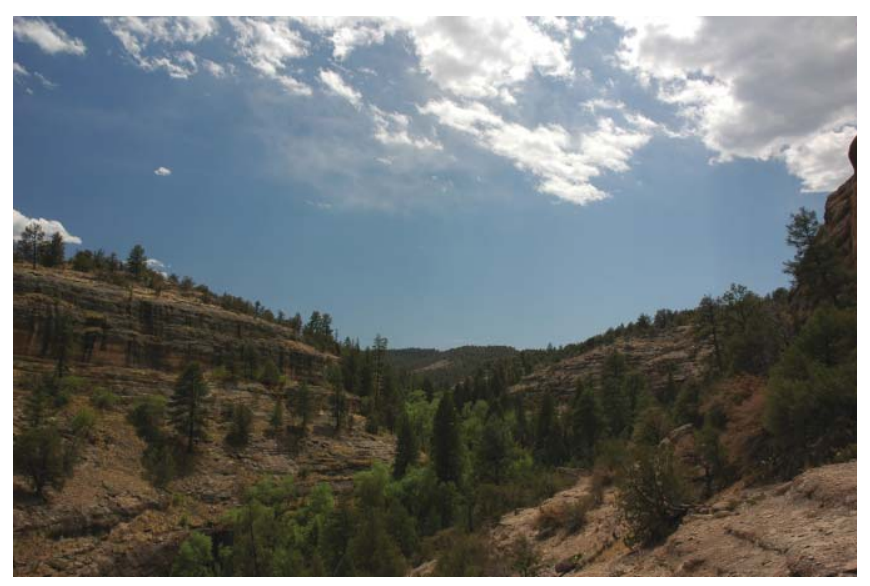

Arizona/New Mexico mountains ecoregion within the Gila Wilderness Area. Photo by Katie Northrup.

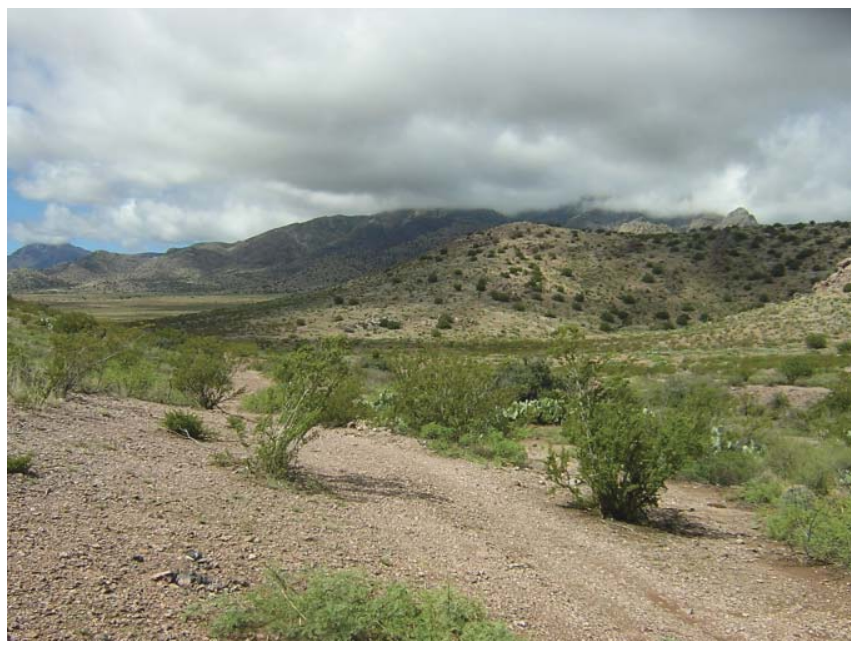

Chihuahuan Desert near Deming, New Mexico. Photo by Lauren Svejcar.

\section{High Plains}

Higher and drier than the Central Great Plains to the east, much of the High Plains is characterized by smooth to slightly irregular terrain supporting a high percentage of cropland. The southern and larger portion of the New Mexico High Plains is occupied by the Llano Estacado (translated as "staked plain"), a mostly treeless, elevated plain surrounded by escarpments on three sides, and once covered by shortgrass prairie composed of buffalograss, blue and sideoats grama, and little and silver bluestem. Bison were once prominent inhabitants. Within this shortgrass prairie are large expanses of shin-oak, a diminutive oak species that spreads through sandy ground by runners and root sprouts. Most of the Llano is now tilled for agriculture.

\section{Southwestern Tablelands}

The Southwestern Tablelands lie across the central portions of the state, with transitions to all surrounding ecoregions. The natural vegetation in this region is mostly shortgrass plains of blue grama, buffalograss, sideoats grama, little

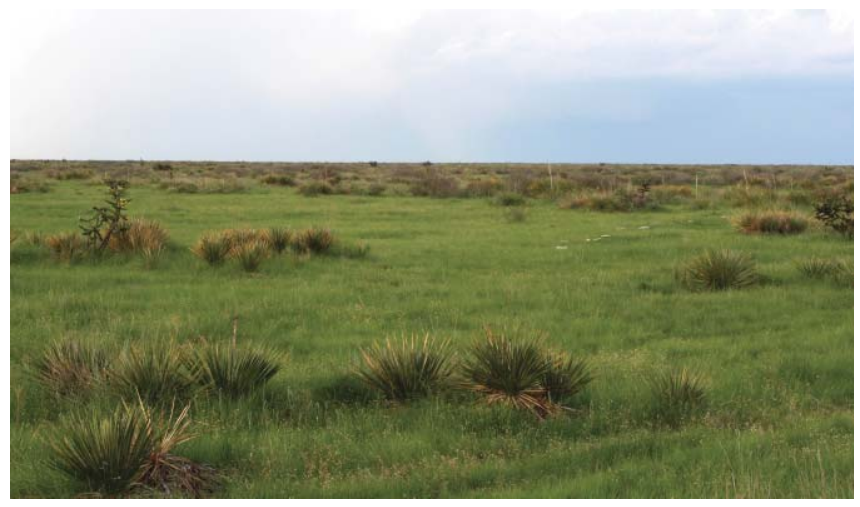

High Plains near Milnesand, New Mexico. Photo by Rob Strahan. 


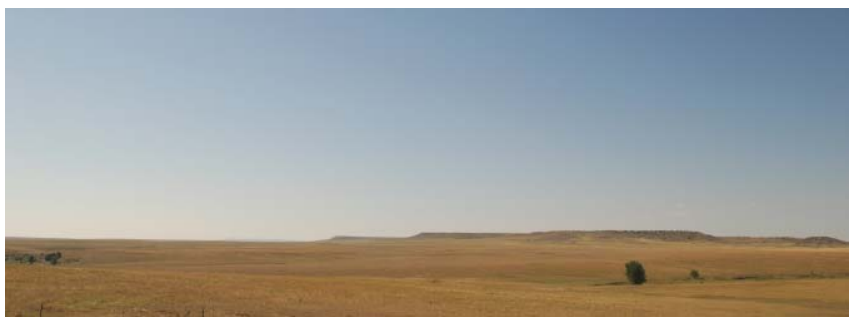

Southwestern Tablelands at Johnson Mesa. Photo by Katie Northrup.

bluestem, western wheatgrass, alkali sacaton, and galleta, but extensive stands of juniper-scrub occur. False buffalograss occurs on degraded or highly disturbed areas. Common shrubs are one-seed juniper, sand sagebrush, skunkbush sumac, and yucca. Piñon-juniper woodlands and savannas are particularly well-developed on thin soils.

\section{Madrean Archipelago}

The Madrean Archipelago ecoregion is present in the southwestern bootheel of New Mexico, and is characterized by low-elevation basin and range topography. Much of the

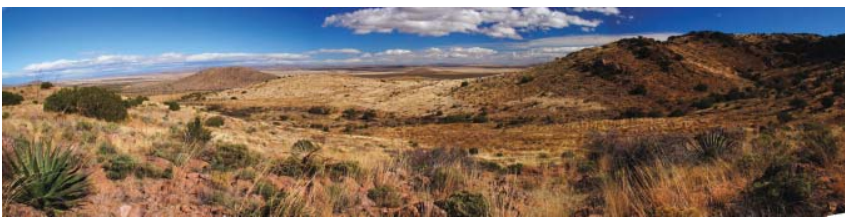

Madrean Archipelago, Elbrock Ranch southwest of Animas, New Mexico. Photo by Rodrigo Sierra Corona.

vegetation is similar to the surrounding Chihuahuan Desert, but with additional species creeping northward from the Sierra Madre of Mexico. The dry, desertic mountains contain evergreen oaks (Emory, silverleaf, Arizona) and various Mexican pines, with scattered piñon, juniper, mesquite, and chaparral species. Riparian areas of cottonwood, sycamore, and willow are valuable to neotropical birds and other wildlife of the area.

Author is Professor, Range Plant Taxonomy, Animal and Range Sciences, New Mexico State University, Las Cruces, NM 88003, USA, kallred@nmsu.edu.

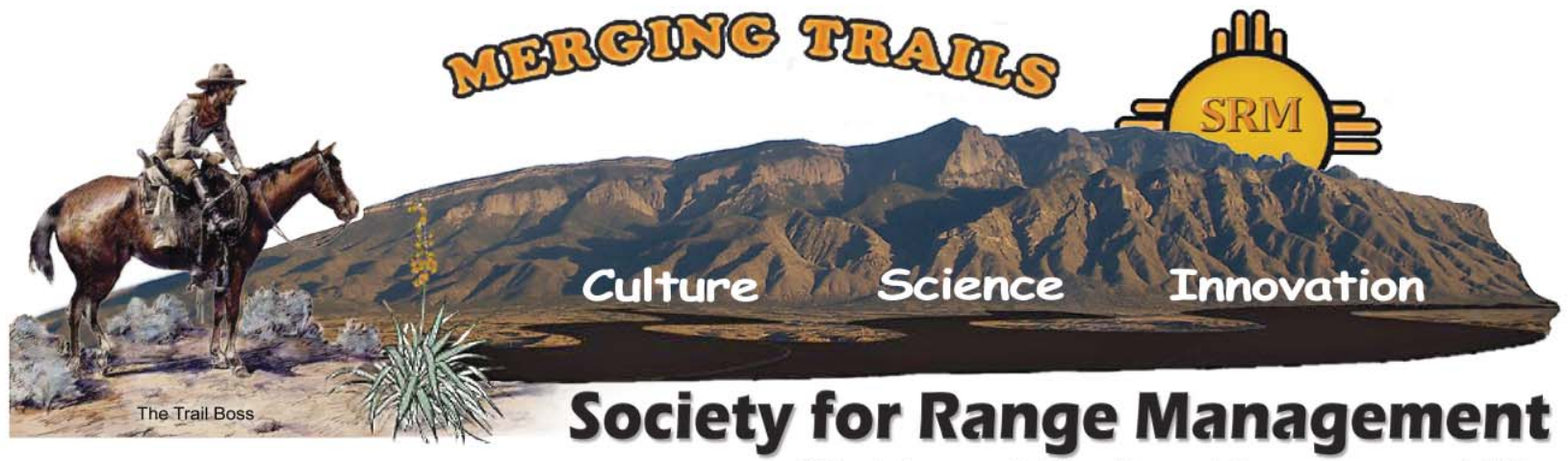

62nd Annual Meeting, Albuquerque, NM

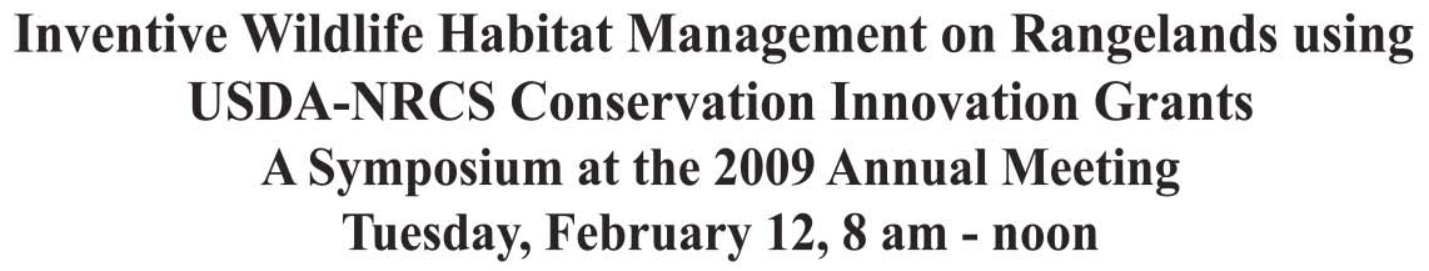

"Conservation Innovation Grants" is a voluntary U. S. federal program designed to stimulate development and adoption of innovative conservation practices and technologies that enhances environmental protection while meeting agricultural production goals. Environmental Quality Incentives Program funds are used to award competitive grants to tribes, individuals, and non-federal entities. These awards enable the National Resource Conservation Service to work with public and private entities to accelerate technology transfer and adoption of promising approaches addressing priority natural resource concerns. During this symposium we will highlight innovative grant projects focusing on wildlife habitat improvements on grazed lands. 